Copyright (C) 2019 by Academic Publishing House Researcher

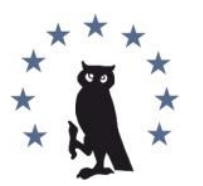

Published in the Russian Federation

European Researcher. Series A

Has been issued since 2010.

E-ISSN 2224-0136

2019, 10(3): 187-195

DOI: $10.13187 /$ er.2019.3.187

www.erjournal.ru

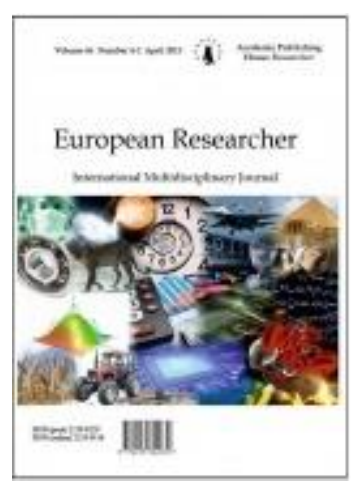

\title{
The Role of Society in Law Enforcement Related to the Eradication of Corruption Crimes
}

\author{
Sri Wulandari a , * \\ ${ }^{a}$ Universitas 17 Agustus 1945, Semarang, Indonesia
}

\begin{abstract}
In eradicating corruption crimes, society's aspirations are needed and have an important role as social control. Therefore, it is necessary to intensify efforts to prevent and eradicate corruption while upholding human rights and the interests of society. This research was conducted using qualitative descriptive methods. In legal research, it generally applies statute approach, case approach, historical approach, comparative approach, and conceptual approach. Based on Law No. 20 of 2001 concerning Amendments to Law No. 31 of 1999 concerning the Eradication of Corruption Crimes, corruption was expressly formulated as formal crime. It means that even though the results of corruption have been returned to the state, the perpetrators of corruption will still be brought to justice and the judicial process applies the burden of reverse proof that is limited or balanced. It turns out that, in this Law, the defendant's statement is not a strong evidence because it only becomes a supporting tool to the existing evidence. This provision has become a weakness in eradicating corruption crimes because the position of the defendant's strong statement will be a valid evidence and a legal basis for the judge to impose a criminal sentence.
\end{abstract}

Keywords: corruption crimes, law enforcement, society.

\section{Introduction}

Corruption is a systematic act that harms state finances. Corruption crimes continue to increase in quality and quantity and is very influential on the declining quality of society's welfare. Corruption is an extraordinary crime. Therefore, it is the responsibility of all elements of society and the availability of legal instruments to eradicate corruption crimes together because corruption is not only a legal problem but also a social and psychological problem; so, it requires simultaneous improvement.

To reach the various modus operandi of state finances/economic deviations that are increasingly sophisticated and complicated, corruption crimes need to be formulated in such a way. It includes the act of enriching oneself or another person/a corporation which is "against the law" in a formal and material sense.

Formulation of understanding of against the law in corruption crimes can include misconduct that can be prosecuted and convicted. In Law No. 20 of 2001 concerning Amendments to the Law of the Republic of Indonesia No. 31 of 1999 concerning the Eradication of Corruption Crimes, corruption is expressly formulated as a formal crime which is very important in proof. It means that in accordance with the formal legal procedure/Criminal Procedure Code, even though

\footnotetext{
${ }^{*}$ Corresponding author

E-mail addresses: ndari904@gmail.com (S. Wulandari)
} 
the results of corruption have been returned to the state, the perpetrators of corruption crimes remain criminalized and the judicial process applies reverse proof that is limited or balanced. In this case, the defendant has the right to prove that he/she has not committed corruption crimes and is obliged to provide information about all his/her assets which are allegedly related to the case and the public prosecutor is still obliged to prove his/her indictment.

Therefore, a good ethic is needed to eradicate corruption crimes through integrated cooperation between law enforcement subsystems and intensive society support because criminal sanctions alone cannot guarantee the reduction in corrupt behavior of the society; therefore, prevention efforts are needed. The problem of corruption is not only related to legal and enforcement issues but it also concerns moral/ mental attitude, lifestyle/economic, cultural, social environment, and bureaucracy/administration. Thus, the criminogenic conditions associated with the emergence of corruption are very broad/multi-dimensional.

In law enforcement practices, the law is apparently not an effective remedy for dealing with corruption because shocking things - especially in handling corruption cases - often occur. It causes apathy/sense of public dissatisfaction with the weak professionalism of law enforcement officers. On the other hand, various obstacles also obstruct the law enforcement process; starting from the lack of evidence, the weakness of the public prosecutor in applying the indictment articles, and the conviction that does not reflect justice/ deterrent effect (disparity in criminal corruption). Therefore, as the spearhead of law enforcement, investigators are required to be professional in gathering legal facts. In addition, it requires guidelines on the provision of sentences without reducing the independence and freedom of judges.

To prevent the development of corruption crimes, anticipation through integrated steps in formal and material law enforcement is needed, i.e. by involving the participation of the society because civil society has a significant share in the occurrence of corruption crimes. Thus, their involvement in overcoming corruption is a necessity as social control.

The direction of eradicating corruption is clear, eradication institutions/ institutions have been made and the laws and regulations are in place. If all of that can go well and precisely, we no longer need to worry about the dangers of corruption.

Based on the description above, the scope of the problem in this study is about how the society's participation in law enforcement in eradicating corruption crimes and its constraints?

\section{Research Method}

This research applies descriptive qualitative method. Descriptive research is research that aims to explore, clarify, describe the state of the research object or subject of a person, institution or society systematically, factually and accurately about a phenomenon or social reality, facts, properties, and relationships between phenomena under research with describe a number of variables related to the research problem. Meanwhile, in qualitative research, theory is interpreted as a paradigm.

In legal research, it usually applies statute approach, case approach, historical approach, comparative approach, and conceptual approach.

The author aims to describe/ present social phenomena directly based on indicators of the presence or absence of a phenomenon being investigated regarding the nature of the relationship between society participation and law enforcement related to the eradication of corruption crimes. The next objective is to find out the deviant behavior of the corruptors as extra ordinary crime. Thus, eradicating corruption is a joint responsibility of the society simultaneously based on legal materials that have relevance which includes primary legal materials, secondary legal materials, tertiary legal materials, as well as open and closed questionnaires using interview techniques based on preliminary data that the author obtained previously.

Informants in this research were obtained using snowball sampling technique. it is a technique for determining the sample, which was initially small in number and then enlarged. In this case, it includes law enforcement officers (police/ prosecutors), and the society (Article 1, Article 9, Article 11, Article 13, Article 22, Article 29, and Article 30 of Law No. 30 of 2002 concerning the Eradication Commission Corruption).

The research setting is Semarang City. As the capital of a province in Central Java, Semarang society has not been involved as subjects in the implementation of law enforcement against corruption. Thus, it becomes an obstacle indicator in finding, obtaining and providing 
information/ data for law enforcement. The author considers that the problem of handling the eradication of corruption is not easy because corruption has taken root/ poisoned the lives of Indonesian society. Therefore, it requires quality and integrity in law enforcement that provides a sense of justice for the society and society participation is very important as a social/ supervisory control in law enforcement to eradicate corruption crimes.

\section{Discussion}

3.1. The Importance of Society's Role in Law Enforcement related to the Eradication of Corruption Crimes

Corruption crimes is a term familiar to Indonesian society. The enormous impact of corruption is a serious problem on society's welfare. That is certainly not an easy thing to solve the problem of corruption. Thus, all elements of society must be involved because corruption is a white-collar crime; i.e. crimes committed by people who have excessive wealth and are considered "honorable" because they have an important position in government and in the economic field.

Perpetrators of corruption are not careless people because they have access to corruption by abusing their authority, opportunities or facilities. Corruption is the misuse of public office for personal gain by illegitimate giving of bribes or commissions.

Corruption crimes are evil and inhumane acts because their effects can damage the joints of society's lives. Corruption is not only carried out by individual state administrators but also through cooperation between state officials and other parties who need services; for instance, businessman, family, friends and cronies. Therefore, this cruel practice of corruption crimes is difficult to eradicate. Nevertheless, the government has made various efforts to prevent and eradicate corruption through preventive and repressive efforts; including by involving the society personally and organizationally. However, up to now, there are still many corruptors who carry out their actions even though the threat of criminal sanctions is very severe and causes strong reactions from the society (social sanctions).

One way of society efforts to eradicate corruption crimes is contained in Government Regulation No. 71 of 2000 and Article 41 paragraph (5) and Article 42 paragraph (5) of Law No. 31 of 1999 concerning Eradication of Corruption Crimes which has been amended by Law No. 20 of 2001.

Article 45 Paragraph (5) and Article 42 Paragraph (5), emphasize the procedures for carrying out society participation and giving awards in the prevention and eradication of corruption crimes. The role of the society is intended to make the rights and responsibilities of the society in law enforcement a state that is clean from corruption.

In addition to Government Regulations, provisions regarding the importance of society participation in the prevention and eradication of corruption crimes are also listed in Article 1, Article 9, Article 11, Article 13, Article 22, Article 29 and Article 30 of Law No. 30 of 2002 concerning the Corruption Eradication Commission, as follows:

Article 1.

"Eradication of corruption crimes is a series of actions to prevent and eradicate corruption crimes through coordinating, supervising, monitoring, investigating, checking, prosecuting and examining in court hearings with society participation based on applicable laws and regulations".

Article 9 and Article 11.

“.... reporting corruption crimes (public complaints)".

Article 13

“.... carrying out education, outreach and anti-corruption campaigns".

Article 22, Article 29, and Article 30.

“.... following/ overseeing the process and mechanism of the nomination and election of members of the Corruption Eradication Commission".

Society participation in the prevention and eradication of corruption crimes is the right to exercise social control which is realized in the form of seeking, obtaining, providing and/or information about corruption crimes and the right to submit suggestions and opinions responsibly, in accordance with the principle of openness in a democratic country. Therefore, openness and freedom to use rights must be accompanied by responsibilities to convey the facts and/or actual events in accordance with statutory provisions. 
Government Regulation No. 71 of 2000 also regulates the obligations of officials/commissions authorized to provide answers or reject the contents of information, suggestions or opinions from every person, non-government organization. On the contrary, the society has the right to submit complaints, criticisms and suggestions even though basically what is submitted by the society often does not get a good and correct response from the official/ commission authorized.

Society participation should not only be made an object in the administration of the state but must be involved as a subject or viewed from one side to use its right to deliver information responsibly. Considering the important role of the society in efforts to prevent and eradicate corruption crimes that are manifested in the form of seeking, obtaining, providing data or information about corruption crimes and the right to submit suggestions and opinions responsibly, it is important to give an award/ appreciation to provide motivation for the society that serves/play an active role as formulated in Article 7 to Article 11 Government Regulation No. 71 of 2000.

Meanwhile, law enforcers or commissions must keep confidential the possibility of knowing the identity of the reporter or the contents of the information, suggestions or opinions submitted. In addition, at the request of the reporter, law enforcement or commission can provide physical security to the reporter and his/ her family if needed.

Before the entry into force of Law No. 31 of 1999 in conjunction with Law No. 20 of 2001, the legal basis of society participation in helping efforts to prevent and eradicate corruption crimes, are the provisions contained in:

a. Article 108 paragraph (1) of the Criminal Procedure Code, that every person who sees, witnesses and/ or is a victim of a crime, has the right to submit a report or report to the investigator and/or examiner verbally or in writing.

b. Article 108 paragraph (3) of the Criminal Procedure Code, that in the context of carrying out its duties, every civil servant who is aware of the occurrence of a crime must report it to the investigator or examiner immediately.

After the enactment of Law No. 31 of 1999 in conjunction with Law No. 20 of 2001, society members who participated in preventing and eradicating corruption were given legal protection and respect.

3.2. Law Enforcement against Corruption Crimes

One important aspect of the rule of law is the issue of enforcement. The rule of law is considered to be effective if it can be implemented and sanctions can be enforced when crimes occur.

According to Moeljatno, crime is an act that is prohibited by a prohibited law which is accompanied by threats (sanctions) in the form of certain crimes for those who violate the prohibition.

Corruption crimes are considered as extra ordinary crime. So, it requires legal instruments that specifically regulate corruption. This special arrangement is needed because the rules in the Criminal Code are seen as no longer sufficient to be applied in the eradication of corruption crimes.

As stated by Eddy OS Hiariej, in criminology, a crime is qualified as an extra ordinary crime if it meets 7 (seven) criteria, as follows:

a. The crime has a very broad and multi-dimensional impact of victimization;

b. The crime is transnational, organized and supported by modern technology in the field of communication and informatics;

c. It is a predicate crime of money laundering crimes;

d. It requires special criminal procedure arrangements;

e. It requires special supporting law enforcement institutions with broad authority;

f. Crimes are based on international conventions which are treaty-based crimes;

g. The crime is super mala per se (very evil and despicable) and is highly condemned by the society both nationally and internationally.

Regarding corruption, the modus operandi is by issuing policies framed by a legal product, such as licensing and filling positions with local government agencies. Eddy OS Hiariej added that political bribery is defined as the legislative power of the legislative institution, including the disbursement of the budget by the commission in the House of Representatives in charge of certain projects. 
Corruption prevention by the Corruption Eradication Commission should be appreciated given the large number of reports of gratuities. It means there is awareness from the state administrators to report the receipt of money suspected of gratuity/corruption results to the Corruption Eradication Commission. This is a sign that the suspects and witnesses tend to be willing to cooperate with the Corruption Eradication Commission and are willing to provide honest information to expose corruption cases.

This cooperative attitude is very helpful in handling corruption cases because most of those who return money also acknowledge their actions and expose the involvement of other parties. This cooperative attitude is influenced by several factors such as:

a. Law enforcement officials are applying better and better investigation methods;

b. Personal awareness of corruptors;

c. A family that reprimands and reminds;

d. Feelings of guilt perpetrators of corruption who think that hiding crime is useless because investigators already know what they did.

The problem that is often faced in the corruption crimes examination is the difficulty in finding and collecting evidence by charging it to the investigator and public prosecutor in proving the defendant's mistake. As a result, many cases of corruption crimes have been decided free of cases.

In addition, there is also the burden of reverse proof set forth in Law No. 3 of 1971 and Law No. 31 of 1999, where the defendant is required to provide information about all his/ her wealth or assets so that the burden of proof becomes the defendant's obligation. In addition, this Law also requires public prosecutors to carry out limited and balanced reverse proof. However, the defendant's statement is not strong evidence because it is only a supporting tool for the existing evidence. In fact, in order to eradicate corruption crimes, the defendant's statement is very much needed and becomes the basis for the judge to comply with the verdict. In addition, the provisions of the defendant's statement which are dependent on other evidence actually become a weakness in the eradication of corruption crimes.

Seeing the impact of corruption that is so powerful and very detrimental to society, seriousness is needed in law enforcement related to the eradication of corruption crimes. Related to the issue of law enforcement, Barda Nawawi Arief argues that law enforcement is upholding the values of truth and justice. It means that law enforcement is trusted by the society to uphold the values of truth and justice. Then, law enforcement has a very important side; i.e. the role of society which is referred to as social control.

Satjipto Raharjo (2000; 175-183) expressed his opinion that law enforcement is the concrete implementation of law in society's lives.

Society participation in efforts to prevent corruption crimes can be given in the form of optimal social control and supervision of state administrators. Furthermore, the society implements good religious and moral values on family members or by providing information directly or in writing regarding the alleged corruption crimes to law enforcement and/ or Corruption Eradication Corruption.

Meanwhile, Abdul Fickar, a lecturer in criminal law at the Trisakti University in Jakarta, reminded that according to the Corruption Crimes Act, returning corrupt money will not eliminate crime. However, it is still counted as something that relieves punishment and gives the impression to law enforcement officials that they are cooperative so that it is expected to ease their sentence. A number of suspects hope that the return of corruption money is intended as the basis for filing a justice collaborator or criminal offense who cooperates with law enforcement to uncover certain legal cases in order to be accepted or at least will be considered by judges to receive light sentences.

Moreover, according to Fickar, efforts to prove that the legal steps taken by the Corruption Eradication Commission have an impact on eradicating corruption and at least serve as a reminder for them not to accept money that is indicated as bribes and have involvement with corruption crimes.

On the other hand, we also need to think about the sole investigator of corruption cases; in this case, the Corruption Eradication Commission even though until now the authority to eradicate corruption is still given to the Police of the Republic of Indonesia, the Prosecutor's Office, and the Corruption Eradication Commission. However, the way forward in preventing and combating extra ordinary crime, the substance of the law and professionalism of law enforcement officers is not 
enough to be able to deal with crime effectively and efficiently. Therefore, the success of crime prevention is not only seen from the aspect of action alone but also prevention and the main thing is public legal awareness. This is in line with what M. Friedman said that there are 3 (three) things that can affect the operation or enforcement of a law, as follows:

a. Legal substance;

b. Legal structure; and

c. Legal culture, which is the mental attitude and behavior of the society towards the existing legal norms.

Society involvement to exercise social control over governance practices is very much needed. It means that the society is not only a spectator in the administration of the state or how the law is enforced, but the society must also play an active role in efforts to prevent and eradicate corruption.

Until now, there is a tendency that all problems can only be solved through the law. In fact, a law will be meaningful if it is implemented and enforced in practice. We must realize that criminal sanctions alone cannot guarantee the decline in corrupt behavior in society because corruption is related to various issues which not only cover legal and enforcement issues but also include moral/mental attitude, lifestyle/economic, cultural and social environment issues.

Corruption crimes have had a tremendous impact. According to Yudi Kristiana, the extraordinary level of corruption development is caused by handling corruption that is not in line with public expectations.

Efforts to eradicate corruption began from the investigation to the reading of the verdict. The similarity in the number of sentences handed down by judges on corruption cases with different amounts of state losses touches a sense of injustice (disparity in corruption crimes). Therefore, guidelines for giving sentences are needed without reducing the independence and freedom of judges in hearing cases.

The issue of criminal disparity in corruption cases seriously hurts the society's sense of justice and raises many questions about the objectivity of judges. Criminal disparity in corruption cases can occur because:

a. There are minimum criminal rules in a number of different articles; thus, the judge has the freedom to use whichever article he/she wishes;

b. The educational background of the judge influences the understanding of the review of the rule of law;

c. Different views of the society in assessing crimes;

d. The absence of guidelines for granting judgments in judging corruption cases.

Although the criminal procedure guideline to prevent criminal disparity has been owned by a number of law enforcement agencies with the aim of preventing and minimizing disparity, the strategy is not considered optimal. Thus, it requires a task force in the field of law enforcement regarding the importance of transparency in handling cases such as the publication of decisions online. Since corruption with all its derivatives is the nation's main enemy, which contributes to poverty and deteriorating society gaps. In addition, we all encourage the Corruption Eradication Commission to continue to clean the nation and state from corruption and demand severe penalties including revocation of political rights for the perpetrators.

3.3. Definition of Corruption and Elements of Corruption Crimes

Corruption comes from the Latin word "corruption" or "corruptus" which then appears in English and French "corruption". In Dutch, it is called "korruptie" and henceforth in Indonesian it is called "corruption".

The term corruption was first present in the repertoire of Indonesian law in Rule of War No. Prt/Perpu/013/1858 concerning Regulations to Eradicate Corruption. Then, it is also included in Law No. 24/Prp/1960 concerning the Investigation, Prosecution and Examination of Corruption Crimes. This Law was later revoked and replaced by Law No. 3 of 1971 concerning the Eradication of Corruption Crimes. Then, since August 16, 1999, it was replaced by Law No. 31 of 1999 and will be effective no later than 2 (two) years later (August 16, 2001). Then, it is amended by Law No. 20 of 2001. Literally, corruption is something rotten, evil, and destructive.

The meaning of corruption can be the following:

a. Crime, decay, can be bribed, immoral, depravity, dishonesty (S. Wojowasito-WJS Poerwadarminta, English-Indonesian Dictionary, Indonesian-English, Publisher: Hasta, Bandung), 
b. Rotten acts such as embezzlement of money, receipt of bribes and so forth. (WJS Poerwodarminto, Indonesian Dictionary, Publisher: Balai Pusaka, 1976),

c. Corrupt (rotten, likes to receive money/ bribe using power for their own interests and so forth),

d. Corruption (foul acts such as embezzlement, receipt of bribes and so forth).

Thus, the conclusion can be drawn that in fact the term corruption has a very broad meaning:

a. Corruption: Misappropriation or embezzlement (state or company money, etc.) for personal and others interests.

b. Corruption: Rotten and corrupt acts, like using goods or money entrusted to him/her, can be bribed (through his/ her power for personal gain).

Corruption always gets more attention compared to other crimes. This phenomenon can be understood considering its impact can touch various fields of life.

All agreed that corruption in Indonesia falls into the category of extraordinary crime. The extraordinary is not only in terms of losses caused but also the power of the perpetrators of corruption that is so terrible. Therefore, in handling corruption cases, it should use the foundation of "eradicate corruption without corruption".

Corruption is an act which enriches oneself or another person which is against the law and directly or indirectly harms the state's finances or the state's economy. Corruption crimes can also mean an offense due to bad deeds, rotten, evil, corrupt or bribery.

Law No. 20 of 2001 concerning amendments to Law No. 31 of 1999 concerning Eradicating Corruption Crimes, determines the penalties for corruption crimes due to the following matters:

a. Anyone who violates the law commits an act or enriches himself or another person or a legal entity that directly or indirectly harms the state's finances and/ or is reasonably known to suspect that these acts are detrimental to the state's finances or the state's economy;

b. The opportunity or means that he/ she has because of his/ her office or position that can directly harm the state's finance or economy;

c. Whoever commits a crime as stated in Article 209, Article 210, Article 387, Article 388, Article 415, Article 416, Article 418, Article 419, Article 420, Article 423, Article 425 and Article 435 of the Criminal Code;

d. Anyone who gives gifts or promises to a Public Servant or state administrator as intended in Article 1 bearing in mind a power or an authority attached to it in his/her office or position or by the promoter attached to that office or position;

e. Whoever without a reasonable reason within the shortest possible time after receiving the gift or promise given to him/ her as mentioned in Article 418, Article 419 and Article 420 of the Indonesian Criminal Code does not report such a gift or promise to the party have the authority;

f.Whoever tries or agrees to commit crimes in paragraphs $1 \mathrm{a}, \mathrm{b}, \mathrm{c}, \mathrm{d}$, e of this Article.

In addition, the elements of corruption crimes are as follows:

a. Doing self-enriching deeds.

The act of enriching oneself means doing anything; for instance, taking, transferring, signing contracts and so forth.

b. The act is an act against the law.

Against the law here is defined formally and materially. This element needs to be proven by the authorities and stated explicitly in the offense formula.

c. This act directly or indirectly harms the state's finances and or the state's economy or it is presumed by the maker that it is detrimental to the state's finances or the state's economy.

The expectation of the government and the community to get priority in resolving corruption cases in the legal sector apparently does not show many positive results, sometimes even going wrong. This is allegedly because law enforcement is too compromising with power holders in all forms of intervention. Moreover, most of the perpetrators of corruption are the holders of power or politicians, bureaucrats, officials of State-Owned Enterprises (SOEs) and private parties who have relations with the authorities.

According to the deputy chairman of the Corruption Eradication Commission, Laode M Syarief, efforts to eradicate corruption are not easy. It cannot be separated from economic control by a group of people to perpetuate their power. In fact, the oligarchs also contributed to the increase of corruption in Indonesia. Thus, the eradication of corruption needs to be supported by 
strong political commitments from state leaders. In this case, weak political commitment has an impact on efforts to eradicate corruption.

Meanwhile, to promote society participation in law enforcement in combating corruption crimes also faces many obstacles. There are many obstacles in practice, such as:

a. The society thinks it is futile to report this crime since their report is not followed up and can even be considered as defamation of someone;

b. Society lacks confidence in the intention of the government and law enforcement officials to implement Government Regulation No. 71 of 2000; thus, public trust in law enforcement officials needs to be built;

c. Corruption is closely related to the complexity of other problems, such as mental/moral attitudes, patterns of life, social culture and economic demands;

d. Disparity in punishment of corruptors so that law enforcement does not cause a deterrent effect and injures a sense of justice.

These constraints hamper the optimal handling of corruption cases in Indonesia because there are many corruption cases that do not go to court on the grounds that there is not enough evidence to ensnare the perpetrators/corruptors. Thus, the case files submitted by investigators to the prosecutor's office were rejected/returned so that the success of the eradication of corruption crimes is strongly influenced by internal factors of law enforcement itself.

\section{Conclusion}

As social control and supervision, direct and indirect society participation is very important in law enforcement regarding eradicating corruption crimes. However, it is meaningless if it is not supported by the quality and integrity of law enforcement institutions. In the reverse verification system, the defendant's testimony can be a strong evidence. The defendant's testimony, which depends on other evidence, is actually a weakness in the eradication of corruption. Meanwhile, the problem of corruption crimes criminal disparity has hurt society's sense of injustice; thus, it raises the nature/feeling of apathy in providing information/reports in terms of eradicating corruption. Although the Laws and Government Regulations have been enacted, the public lacks confidence in the good intentions of the government and law enforcement. In the future, efforts to restore this stigma need to be carried out by rebuilding public trust through enhancing the integrity of the state apparatus.

\section{References}

Barda, 2008 - Barda Nawawi Arief (2008). Masalah Penegakan Hukum Pidana Dalam Penanggulangan Kejahatan, Jakarta: Kencana Prenada Media Grup.

Eddy, 2018 - Eddy OS Hiariej (2018). Penegakan Hukum Kejahatan Luar Biasa, Kompas, jumat 28 Desember.

Elwina Marcella, 2011 - Elwina S. Marcella (2011). Pendidikan Anti Korupsi: Sebuah Langkah Pendidikan Integritas di Semarang, 5 Juli.

Febri Diansyah, 2019 - Febri Diansyah (2019). Juru Bicara KPK, Kompas, Selasa 12 Maret.

Friedman, Lawrence, 1975 - Friedman, Lawrence M. (1975). The Legal System, A Social Perspective, New York, Russel Sage Foundation.

Harkristuti Harkrisnowo, 2002 - Harkristuti Harkrisnowo (2002). Korupsi, Konspirasi dan keadilan di Indonesia, Jurnal: Dictum LeIP, Edisi I, Jakarta: Lentera Hati.

Law No. 20 of 2001... - Law No. 20 of 2001 concerning Amendments to the Law of the Republic of Indonesia No. 31 of 1999 concerning Eradication of Corruption Crimes.

Law No. 30 of 2002... - Law No. 30 of 2002 concerning the Corruption Eradication Commission.

Litbang..., 2018 - Litbang Kompas/Ida Ayu Grhamtika Saitya, 2018, Kompas, 12 Desember.

Marcella Buckley, 2003 - Marcella Buckley (2003). Dalam Hans Otto Sano, et al, Hak Asasi

Manusia dan Good Govermance, Membangun Suatu Ketertiban, (alih bahasa oleh Rini Adriati), Jakarta: DepKumHam.

Moeljatno, 1983 - Moeljatno (1983). Kitab Undang-Undang Hukum Pidana.

Nyoman Putra Jaya, 2008 - Nyoman Putra Jaya (2008). Beberapa Pemikiran Kearah Pengembangan Hukum Pidana, Bandung: Citra Aditya Bakti. 
Republic of Indonesia Government... - Republic of Indonesia Government Regulation No. 71 of 2000 concerning Procedures for the Implementation of Society Participation and the Appreciation of the Prevention and Eradication of Corruption Crimes.

Romli Atmasasmita, 2003 - Romli Atmasasmita (2003). Korupsi, Good Govermance dan Komisi Anti Korupsi di Indonesia, Jakarta: Badan Pembinaan Hukum Nasional Departemen Kehakiman dan Hak Asasi Manusi Republik Indonesia.

Sudarto, 1977 - Sudarto (1977). Hukum dan Hukum Pidana, Bandung: Alumni.

Sudarto, 1981 - Sudarto (1981). Hukum dan Hukum Pidana, Bandung : Penerbit Alumni

Yudi Kristiana, 2008 - Yudi Kristiana (2008). Pendekatan Kritis Terhadap Realitas Kinerja Kejaksaan, Makalah disampaikan dalam Siminar nasional tentang "Strategi Peningkatan Kinerja RI di Undip Semarang, 29 November. 